\title{
Clinical Analysis of Cholesterol Granuloma in the Middle Ear
}

\author{
Hee Sung Chin, Dong Yeol Han, Won Ik Jang, In Hyo Lee, Yi Suk Kim and Byung Don Lee \\ Department of Otolaryngology-Head and Neck Surgery, Soonchunhyang University College of Medicine, Seoul, Korea
}

\section{중이 콜레스테롤 육아종의 임상 분석}

\author{
진희성 · 한동열 · 장원익 · 이인효 · 김이석 · 이병돈 \\ 순천향대학교 의과대학 이비인후과학교실
}

\section{Received October 16, 2009 \\ Revised November 18, 2009 \\ Accepted November 18, 2009}

\section{Address for correspondence}

Byung Don Lee, MD

Department of Otolaryngology-

Head and Neck Surgery,

Soonchunhyang University

College of Medicine,

22 Daesagwan-gil, Yongsan-gu,

Seoul 140-743, Korea

Tel $+82-2-709-9363$

Fax +82-2-794-9628

E-mail bdlee12@hosp.sch.ac.kr
Background and Objectives The Cholesterol granuloma is often observed in middle ear surgeries. In the clinic, it can be found in a normal ear, but also as a recurrent serous otitis media in non-responding medical therapy. The purpose of this study is to analyze the clinical characteristics of cholesterol granuloma with or without cholesteatoma.

Subjects and Method We performed a retrospective study of 40 patients who underwent tympanomastoidectomy between January, 2000 and January, 2009 for cholesterol granuloma. We divided patients into a non-cholesteatoma group and a cholesteatoma group and observed the following clinical manifestations: initial symptom findings, ear drum findings, preoperative audiogram, postoperative audiogram, operative technique and operative findings.

Results Cholesterol granuloma was found in $10.2 \%$ of 393 cases (40 cases) who underwent chronic otitis media surgery. Of these, $5.3 \%$ ( 21 cases) was diagnosed with non-cholesteatoma group and $4.8 \%$ (19 cases) was diagnosed in the cholesteatoma group. Chief complaints were the difficulty of hearing in the non-cholesteatoma group and otorrhea in the cholesteatoma group. Ear drums were nearly retracted and perforated in both groups, although the cholesteatoma group had more damaged ear drum. Distinctive features of hearing were the conductive type with a moderate degree and ossicular destruction showed missing or eroded incus. Major sites of cholesterol granuloma were antrum, air cells and epitympanum.

Conclusion Although ear drum was relatively preserved in the non-cholesteatoma group of cholesterol granuloma, the hearing level and the degree of ossicular destruction were not so much different between the two groups. Therefore, a complete removal of cholesterol granuloma and ossiculoplasty should be considered for better hearing restoration.

Korean J Otorhinolaryngol-Head Neck Surg 2009;52:974-9

Key Words Cholesterol granuloma $\cdot$ Middle ear.

\section{서 론}

측두골 내에서 발생한 콜레스테롤 육아종은 중이, 유양동 및 추체 첨부 등에서 발견되고 만성 중이염 환자의 12 20\% 정도의 유병률을 가지며, ${ }^{1)}$ 부비동, 폐, 늑막, 종격동, 뇌, 신 장, 갑상선, 안구, 하악, 림프절 및 고환 등 다양한 장기에 서 발생한다. ${ }^{2,3)}$

콜레스테롤 육아종은 병리조직학적으로 콜레스테롤 결절
로 이루어져 있고 그 주위에 이물질 거대세포(foreign body giant cell)가 나타나며, 그 주위 섬유 결체 조직에는 일반 적으로 원형세포, 대식세포 등의 침윤을 특징적으로 볼 수 있다(Fig. 1).

콜레스테롤 육아종의 발생 원인에 대한 가설로는 현재까 지 두 가지가 제시되고 있는데 첫째는 obstruction vacuum theory로 함기세포의 폐쇄로 인해 생긴 음압으로 인해 혈 액의 삼출작용이 발생하고 그로 인해 생긴 혈액성분의 파 
괴가 육아종성 염증을 초래하고 이 과정이 반복되면서 종 괴의 크기가 커지고 골미란을 일으킨다는 이론이고, 둘째 가설은 exposed marrow hypothesis로 측두골 내의 함기 세포가 발달하면서 골수 성분으로 채워진 측두골의 미란이 발생하여 골수로부터 함기세포 내로 출혈이 발생하여 위와 같은 과정이 발생한다는 이론이다. ${ }^{4.5)}$

측두골에 발생한 콜레스테롤 육아종은 이소골 파괴, 난청, 안면신경마비, 미로 손상 및 두개 내 합병증을 일으키며, 비교적 고막손상이 적고, 임상 증상이 경증인 경우에도 진 행된 중이 병변을 보이는 경향이 있다.

이에 저자들은 중이 콜레스테롤 육아종의 진주종 동반 여부에 따른 이소골 파괴의 정도, 이소골 손상 부위, 청력 소실 정도, 고실 성형술 시행 여부 및 콜레스테롤 육아종 의 발생위치를 비교하기 위하여 두 군으로 분류하여 임상 적 양상을 분석하였으며, 중이 콜레스테롤 육아종의 치료 방침 결정에 도움이 되고자 하였다.

\section{대상 및 방법}

2000년 1월부터 2009년 1월까지 9년간 본원에서 만성 및 진주종성 중이염으로 수술을 받은 환자 중 393예에서 수술 후 조직병리검사를 시행하였고, 콜레스테롤 육아종으 로 확진된 40예를 대상으로 진주종성 중이염이 동반된 19 예와 진주종성 중이염이 동반되지 않은 21 예의 초진 시 증

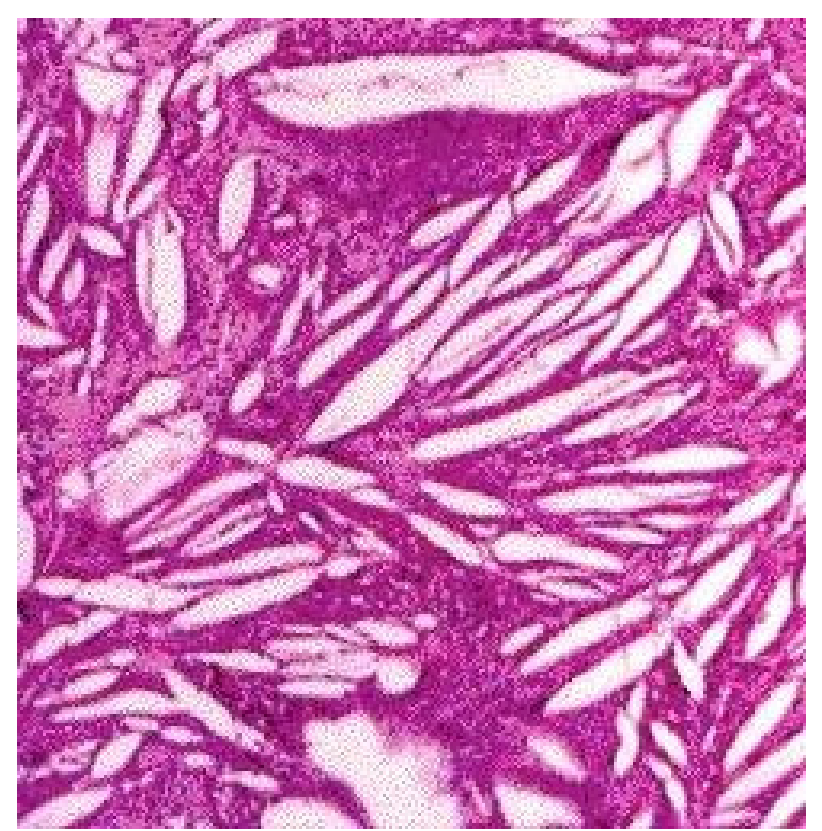

Fig. 1. Pathologic finding: photomicrograph of numerous cholesterol clefts surrounded by foreign body giant cells and granulation tissue $(H \& E$ stain, $\times 100)$.
상, 고막 소견, 수술 전 후 청력검사, 수술 방법 및 소견 등 을 토대로 후향적 분석을 하였다.

수술 전 청력은 $0.5 \mathrm{kHz}, 1 \mathrm{kHz}, 2 \mathrm{kHz}, 3 \mathrm{kHz}$ 의 청력역 치를 4 분법으로 평가하였으며, 전음성, 감각신경성 및 혼합 성 난청으로 분류하였다. 수술 방법은 대한이과학회의 만 성 중이염 수술의 분류 표준지침에 따랐다. 유양동 절제술의 경우 공동폐쇄 유양동 절제술(canal wall-up mastoidectomy, CWUM) 과 공동개방 유양동 절제술 (canal walldown mastoidectomy, $\mathrm{CWDM}$ )로 분류하였고, 동시에 시 행하였던 고실 성형술의 경우는 tympanoplasty type 1 부 터 type 4까지 이소골 손상에 대한 재건을 시행한 군(tympanoplasty)과 tympanoplasty type 0 만 시행한 군(tympanization)으로 분류하였다. 수술 소견으로는 콜레스테롤 육아종의 위치, 이소골 파괴 부위 및 안면신경 골벽 결손 등 을 분석하였다. 통계학적 유의성 검증은 Chi-square test, Mann-Whitney test, t-test 및 선형회귀 분석을 시행하 였고, 유의수준은 $p<0.05$ 로 하였다.

\section{결 과}

전체 만성 중이염 수술 환자 중 393예에서 조직검사를 시행하였고, 수술 후 병리학적 확진을 받은 콜레스테롤 육 아종은 40 예로 $10.18 \%$ 였다. 만성 중이염과 속발된 콜레스 테롤 육아종인 경우(비진주종성)가 21예(5.34\%), 진주종 성 중이염과 동반된 경우가 19예(4.84\%) 였다. 연령 분포 는 두 군 모두에서 8세부터 73세까지 광범위하게 관찰되었 다. 수술 후 추적관찰 기간은 평균 24.5 개월이었다.

\section{초진 시 증상}

비진주종성의 경우, 청력 소실 11예(52.4\%), 이루 9예 (42.9\%), 그 외 이충만감이 1예(4.8\%)로 이루에 비해 청 력저하를 호소하는 경우가 많았으며, 진주종성의 경우에는 이루 11예(57.9\%), 청력 소실 7예(36.8\%), 이통 1예(5.3 $\%)$ 로 청력저하에 비해 오히려 이루를 호소하는 경우가 더 많았다.

\section{고막 소견}

비진주종성의 경우에 정상 고막 1 예 $(4.8 \%)$, 만성 삼출 성 중이염 1 예(4.8\%), 청색 고막 2예(9.5\%), 고막 천공 중 $50 \%$ 미만의 천공 5 예(23.8\%), 50\% 이상 천공이 7 예 (33.3\%), 상고실 함몰 3예(14.3\%) 및 유착성 2예(9.5\%) 였고, 진주종성의 경우에 고막 천공 중 $50 \%$ 미만의 천공 이 1 예 $(5.3 \%), 50 \%$ 이상 천공이 7 예(36.8\%), 상고실 함 
몰 8예(42.1\%), 유착성 3예(15.8\%)였다(Table 1). 통계 적으로 유의한 차이는 없었지만 $(p=0.170)$ 수술 전 고막 소견은 전체적으로 진주종성일 경우에 손상이 심하였으며, 범위가 넓은 경향을 나타내었다.

\section{수술 전후 청력}

수술 전 청력의 평균치는 콜레스테롤 육아종만 있는 경우 기도청력의 평균은 $52.71 \mathrm{~dB}$, 기도골도 청력차의 평균은 $32.71 \mathrm{~dB}$ 이며, 전음성 난청 14 예 $(66.7 \%)$, 감각신경성 1 예 $(4.8 \%)$ 및 혼합성 6예(28.6\%)였다. 진주종이 동반된 경

Table 1. Eardrum findings of cholesterol granuloma

\begin{tabular}{lcc}
\hline & $\begin{array}{c}\text { Non-cholesteatoma } \\
\text { group }\end{array}$ & $\begin{array}{c}\text { Cholesteatoma } \\
\text { group }\end{array}$ \\
\hline Intact & $1(4.8)$ & $0(0.0)$ \\
$\begin{array}{l}\text { Blue drum } \\
\begin{array}{l}\text { Chronic otitis media } \\
\text { with effusion }\end{array}\end{array}$ & $2(9.5)$ & $0(0.0)$ \\
$\begin{array}{l}\text { Perforation (small or } \\
\text { medium size) }\end{array}$ & $1(4.8)$ & $0(0.0)$ \\
$\begin{array}{l}\text { Perforation (more than } \\
\text { large size) }\end{array}$ & $7(23.8)$ & $1(5.3)$ \\
$\begin{array}{l}\text { Attic destruction } \\
\text { Adhesion }\end{array}$ & $3(14.3)$ & $7(36.8)$ \\
\hline Total & $2(9.5)$ & $8(42.1)$ \\
\hline & $21(100)$ & $3(15.8)$ \\
\hline \multicolumn{2}{c}{$p=0.170$. No. of cases (\%) }
\end{tabular}

우 기도청력의 평균은 $53.26 \mathrm{~dB}$, 기도골도 청력차의 평균 은 $35.21 \mathrm{~dB}$ 이며, 전음성 난청 15 예(78.9\%) 및 혼합성 4 예 $(21.1 \%)$ 였다. 두 군 모두에서 전음성 난청이 많았고, 통 계적으로도 유의한 차이를 보이지 않았다 $(p=0.512)$ (Table 2). 청력장애의 정도 또한 비슷하며, 두 군 모두에서 중등도 난청이 21 예로 가장 많았다. 두 군의 환자 중에서, 외래 추 적관찰 가능하였던 비진주종성 환자군 10 명과 진주종성 환 자군 8명에서 술 후 청력검사를 시행하였다. 술 후 전자의 기도청력의 평균은 $47.30 \mathrm{~dB}$, 기도골도 청력차는 24.40 $\mathrm{dB}$ 이며, 후자의 기도청력의 평균은 $43.62 \mathrm{~dB}$, 기도골도 청 력차는 $23.13 \mathrm{~dB}$ 이었다(Table 3 and 4). 수술 후 청력의 경우에도 두 군이 비슷한 예후를 보였으며, 기도골도 청력 의 차도 비슷한 정도로 회복되는 양상이었다. 술 전후의 청 력과 술 전후의 기도골도 청력차 또한 통계적으로 유의한

Table 2. Hearing loss type of cholesterol granuloma

\begin{tabular}{lcc}
\hline & $\begin{array}{c}\text { Non-cholesteatoma } \\
\text { group }\end{array}$ & $\begin{array}{c}\text { Cholesteatoma } \\
\text { group }\end{array}$ \\
\hline $\begin{array}{l}\text { Conductive hearing } \\
\text { loss }\end{array}$ & $14(66.7)$ & $15(78.9)$ \\
$\begin{array}{l}\text { Sensorineural hearing } \\
\text { loss }\end{array}$ & $1(4.8)$ & $0(0.0)$ \\
Mixed hearing loss & $6(28.6)$ & $4(21.1)$ \\
\hline Total & $21(100)$ & $19(100)$ \\
\hline & \multicolumn{2}{c}{$p=0.512$. No. of cases $(\%)$}
\end{tabular}

Table 3. Preoperative and postoperative audiogram (air conduction) of cholesterol granuloma

\begin{tabular}{|c|c|c|c|c|}
\hline & \multicolumn{2}{|c|}{ Non-cholesteatoma group } & \multicolumn{2}{|c|}{ Cholesteatoma group } \\
\hline & Preoperative & Postoperative & Preoperative & Postoperative \\
\hline $0-20 \mathrm{~dB}$ & $0(0.0)$ & $1(10.0)$ & $1(5.3)$ & $2(25.0)$ \\
\hline $21-40 \mathrm{~dB}$ & $6(28.6)$ & $3(30.0)$ & $3(15.8)$ & $1(12.5)$ \\
\hline $41-60 \mathrm{~dB}$ & $10(47.6)$ & $4(40.0)$ & $11(57.9)$ & $4(50.0)$ \\
\hline $61-80 \mathrm{~dB}$ & $4(19.0)$ & $0(0.0)$ & $2(10.5)$ & $0(0.0)$ \\
\hline $81-100 \mathrm{~dB}$ & $1(4.8)$ & $2(20.0)$ & $2(10.5)$ & $1(12.5)$ \\
\hline Total & $21(100)$ & $10(100)$ & $19(100)$ & $8(100)$ \\
\hline
\end{tabular}

Preoperative audiogram $p=0.893$, postoperative audiogram $p=0.965$. Postoperative hearing check was possible in 10 cases of noncholesteatoma group and 8 cases of cholesteatoma group

Table 4. Preoperative and postoperative air-bone gap of cholesterol granuloma

\begin{tabular}{|c|c|c|c|c|}
\hline & \multicolumn{2}{|c|}{ Non-cholesteatoma group } & \multicolumn{2}{|c|}{ Cholesteatoma group } \\
\hline & Preoperative & Postoperative & Preoperative & Postoperative \\
\hline $0-10 \mathrm{~dB}$ & $0(0.0)$ & $1(10.0)$ & $1(5.3)$ & $1(12.5)$ \\
\hline $11-20 \mathrm{~dB}$ & $3(14.3)$ & $2(20.0)$ & $1(5.3)$ & $3(37.5)$ \\
\hline $21-30 \mathrm{~dB}$ & $6(28.6)$ & $4(40.0)$ & $3(15.8)$ & $1(12.5)$ \\
\hline $31-40 \mathrm{~dB}$ & $5(23.8)$ & $3(30.0)$ & $6(31.6)$ & $3(37.5)$ \\
\hline $41-50 \mathrm{~dB}$ & $7(33.3)$ & $0(0.0)$ & $8(42.1)$ & $0(0.0)$ \\
\hline Total & $21(100)$ & $10(100)$ & $19(100)$ & $8(100)$ \\
\hline
\end{tabular}

Preoperative air-bone gap $p=0.247$, postoperative air-bone gap $p=0.740$. Postoperative hearing check was possible in 10 cases of non-cholesteatoma group and 8 cases of cholesteatoma group 
차이를 보이지 않았다 $(p=0.893,0.965,0.247,0.740)$.

\section{수술 방법}

비진주종성 군에서는 유양동 절제술은 CWUM 13예(61.9 \%), CWDM 8예(38.1\%) 시행하였고, 고실 성형술은 tympanoplasty 15예(71.4\%), tympanization 6예(28.6\%)에 서 시행하였다. 비진주종성 군 중 유착성 중이염 2예, 상고 실가 파괴가 심하였던 3 예, 외이도 협착 있는 1 예, 유양동 손상이 심하거나 유양동 내에 콜레스테롤 육아종이 광범위 하게 존재하였던 2예에서 $\mathrm{CWDM}$ 을 시행하였다. 진주종성 의 경우에는 CWUM 5예(26.3\%), CWDM 14예(73.7\%) 시행하였고, tympanoplasty 11예(57.9\%), tympanization 8예 $(42.1 \%)$ 시행하였다. 진주종성의 경우는 상고실 내에 국 한된 진주종 이외의 경우는 모두 $\mathrm{CWDM}$ 을 시행하였다. 비 진주종성의 경우에 $\mathrm{CWUM}$, 진주종성의 경우에 $\mathrm{CWDM}$ 를 주로 시행하는 경향이 있었으며, 통계적으로 유의하였다 $(p=$ 0.024). tympanoplasty를 시행한 경우는 두 군에서 유의 한 차이가 없었다 $(p=0.383)$ (Table 5).

이는 진주종성의 경우에 중이강이나 유양동에 좀더 광범 위한 수술이 필요하였으나, 청력 개선을 위한 이소골 재건 술이 가능한 환자군이 두 군에서 큰 차이가 없었기 때문인 것으로 생각된다.

\section{수술 소견}

수술 소견으로 이소골의 손상은 각 예마다 이소골 연쇄의 여러 곳에 손상이 있었으며 비진주종성 군에서 21 예 중 7
예로(33.3\%), 각각 2예에서 등골 및 추골 손상을 동반한 침골 장각의 손상이 7 예(41.2\%)였다. 진주종성의 경우에 는 19예 중 16예(84.2\%)로 역시 등골 9예 및 추골 7예의 손상과 동반된 침골 장각의 손상이 15예 (28.8\%)였다. 두 군 모두 침골이 가장 많은 손상 부위였다(Table 6). 통계 적으로 진주종이 동반될 경우 이소골의 손상이 유의하게 많 았다 $(p=0.001, \beta=1.927)$. 이소골의 파괴는 진주종이 동 반될수록 증가하고, 여러 부위를 동시에 손상시키는 양상이 었으나 이것은 진주종성 중이염이 이소골 주위에 존재하는 경우가 많아 이소골의 손상이 더 빈번하였기 때문으로 보 이며, 콜레스테롤 육아종이 이소골 근처의 중고실에서 발견 된 경우에는 이소골이 손상이 모든 예에서 발견되었기 때 문에 콜레스테롤 육아종의 골파괴 양상은 진주종과 큰 차 이가 없다고 보여진다.

수술 시 콜레스테롤 육아종의 존재 부위는 각 예에서 한 군데 이상 발견되었고, 진주종성의 경우 주로 유양동 내 10 예(35.7\%) 및 상고실 9예(32.1\%), 진주종성의 경우는 상 고실 8예(29.6\%) 및 중고실과 유양동이 각각 6예(22.2\%) 였다(Table 7).

\section{고 찰}

측두골의 콜레스테롤 육아종은 임상적으로나 조직학적으 로 독립적인 질환이 아닌 측두골의 함기조직 어느 부위에 서나 발생할 수 있으며, ${ }^{6,7)}$ 다양한 형태의 중이질환과 서로 관련이 있고, 콜레스테롤 결절에 대한 조직의 이물질 반응

Table 5. Operation of cholesterol granuloma

\begin{tabular}{ccccccccc}
\hline & \multicolumn{3}{c}{ Non-cholesteatoma group } & & \multicolumn{3}{c}{ Cholesteatoma group } \\
\cline { 2 - 3 } & Tympanoplasty & Tympanization & Total & & Tympanoplasty & Tympanization & Total \\
\hline CWUM & $12(57.1)$ & $1(4.8)$ & $13(61.9)$ & & $3(15.8)$ & $2(10.5)$ & $5(26.3)$ \\
CWDM & $3(14.3)$ & $5(23.8)$ & $8(38.1)$ & & $8(42.1)$ & $6(31.6)$ & $14(73.7)$ \\
\hline Total & $15(71.4)$ & $6(28.6)$ & $21(100)$ & $11(57.9)$ & $8(42.1)$ & $19(100)$ \\
\hline & & & & & & & &
\end{tabular}

Mastoidectomy $p=0.024$, tympanoplasty $p=0.383$. Tympanoplasty: type $1-4$ tympanoplasty, Tympanization: type 0 tympanoplasty. CWUM: canal wall-up mastoidectomy, CWDM: canal wall-down mastoidectomy

Table 6. Incidence of ossicular destructions of cholesterol granuloma

\begin{tabular}{lcc} 
& Non-cholesteatoma group & Cholesteatoma group \\
\cline { 2 - 3 } & No. of destructions (\%) & No. of destructions (\%) \\
\hline Malleus head & $2(11.8)$ & $7(13.5)$ \\
Malleus handle & $3(17.7)$ & $9(17.3)$ \\
Incus body \& SP & $3(17.7)$ & $12(23.1)$ \\
Incus LP \& LnP & $7(41.2)$ & $15(28.8)$ \\
Stapes & $2(11.8)$ & $9(17.3)$ \\
\hline No. of destructions of all cases $(\mathrm{n}=69)$ & $17(100)$ & $52(100)$ \\
\hline
\end{tabular}

Each case had multiple destructions of ossicular chain. SP: short process, LP: long process, LnP: lenticular process 
Table 7. Sites of cholesterol granuloma

\begin{tabular}{|c|c|c|}
\hline & Non-cholesteatoma group & Cholesteatoma group \\
\hline & No. of sites (\%) & No. of sites (\%) \\
\hline Mastoid air cell & $1(3.6)$ & $5(18.5)$ \\
\hline Antrum & $10(35.7)$ & $6(22.2)$ \\
\hline Aditus ad antrum & $4(14.3)$ & $2(7.4)$ \\
\hline Epitympanum & $9(32.1)$ & $8(29.6)$ \\
\hline Mesotympanum & $4(14.3)$ & $6(22.2)$ \\
\hline No. of sites of all cases $(n=55)$ & $28(100)$ & $27(100)$ \\
\hline
\end{tabular}

Cholesterol granuloma was found in various places in each case

으로 발생하는 육아조직을 일컫는 비특이적인 조직병리학 적 명칭이다.

추체 첨부에 생기는 경우를 제외하고는 대부분의 경우에 증상이 없거나 위험하지 않으나 육아종은 이물 반응으로 주 변 조직에 손상을 주는데, ${ }^{8)}$ 이는 콜레스테롤 육아종이 섬 유화와 이물질 거대세포 반응, 공간 내의 압력 감소, 점막 염증, 혈관 생성 및 파열, 헤모글로빈 파괴, 콜레스테롤 결 정체 증가 등으로 주변 조직에 강한 자극과 함께 위의 반응 을 반복적으로 일으킴으로 인해서 발생한다. ${ }^{7)}$

콜레스테롤 육아종의 발생은 성별이나 연령에 관계가 없 었다. 초진시의 증상으로는 비진주종성에서는 난청이었고, 진주종성은 이루가 대부분이었다. 비진주종성 콜레스테롤 육아종의 경우에 고막 소견이나 이루 등이 심하지 않으면 서 중이의 이소골 손상이 진행되어, 난청을 주 증상으로 이 비인후과를 내원하는 것으로 생각된다. 정상 고막이나 청색 고막인 경우에도 발생하는데, 본 연구에서도 각각 1 예와 2 예에서 정상 고막과 청색 고막으로 부분적인 고막의 함몰 을 보인 소아 환자가 있었다. 콜레스테롤 육아종만 존재하 는 경우에는 천공 및 상고실 함몰이나 상고실 파괴 등의 고막소견이 있어도 심하게 손상되어 있지 않은 양상이었다.

만성 삼출성 중이염에서도 중이 내에 국소적으로 발생할 수도 있는 데 ${ }^{9}$ 보존적 치료에도 불구하고 재발하는 경우에 는 방사선 검사를 통해 유양동의 병변을 확진할 필요가 있 으며, 본 연구에서도 삼출성 중이염으로 수차례의 환기튜브 유치술을 시행 하였으나 호전되지 않는 환자에서 CT로 유 양돌기염 진단 하에 수술로 콜레스테롤 육아종을 확진한 환자 1 예가 있었다. 또한 중이 수술을 받은 후에는 상고실 의 유착으로 인한 환기장애로 인하여 발생하며, ${ }^{10)}$ 본 연구 의 3예에서 중이염 수술 후 재수술 시에 확진된 경우로 이 중 1 예에서는 고막은 정상이었으나, 난청을 호소하였다.

진주종성 중이염과 동반된 경우에서 생화학적 연구로 동 일한 기전을 설명하였고, $\left.{ }^{11}\right)$ 특히 진주종의 기질 뒤쪽에서 가장 흔히 관찰되었다고 보고된 바 있으나 ${ }^{12)}$ 본 연구에서 는 진주종성 중이염과 동반된 경우보다는 동반되지 않은 환
자가 2예 더 많았다. 진주종이 주로 상고실이나 유양동 주 변의 유양봉소에 위치하고 있어 진주종으로 인하여 환기 및 배설 기능장애로 콜레스테롤 육아종이 진주종과 자주 동반 되기는 하지만, 일반적인 염증조직 혹은 육아종에 의해서도 환기장애로 인한 콜레스테롤 육아종이 쉽게 발생하기 때문 인 것으로 생각된다.

콜레스테롤 육아종의 골파괴 기전은 Prostaglandin F, Prostaglandin D 및 Hydroxy-eicosatetraenoic acid 등 ${ }^{13)}$ 이 관여함을 보고하였으나 아직 확인되지 않았고, 본 연구 에서 비진주종성 및 진주종성 콜레스테롤 육아종에서 각각 3 예씩 상고실 골부 파괴를 확인하였고, 콜레스테롤 육아종 자체로서 골파괴를 일으키는지, 아니면 단순 만성 염증에 의해서도 발생하는지에 대해서는 앞으로 연구해야 할 항목 이지만 저자들의 환자군에서 콜레스테롤 육아종 주위의 골 조직의 변성 및 미란이 진행되고 있었다. 또한 아직까지 국 내에서는 콜레스테롤 육아종의 이소골 병변에 대한 통계가 거의 없어 확인하기 어렵지만, 일반적인 만성 중이염의 양 상보다 콜레스테롤 육아종을 동반한 경우 이소골의 연쇄의 손상으로 인한 전도성 난청의 진행이 더 빠를 것으로 사료 된다. 본 연구에서도 다양한 이소골 파괴가 있었으며 비진 주종성의 경우에는 대부분이 침골과 등골에서 미란과 소실 이 주로 발견되었다. 진주종성의 경우에는 침골, 등골과 추 골에서의 병변이 보다 광범위하고 더 파괴적인 양상을 보였 으나 이것은 진주종이 이소골 주위에 존재하는 빈도가 높아 이소골의 손상이 더 많이 나타난 것으로 생각되며, 진주종 이 동반된 경우에 CWDM을 시행한 경우가 유의하게 많았 음에도 불구하고, tympanoplasty를 동시에 시행하였던 군 이 비진주종성 군과 유의한 차이가 없었던 것 또한 콜레스 테롤 육아종의 이소골 파괴의 능력이나 중고실의 손상 경 향이 진주종과 큰 차이가 없었기 때문으로 사료된다. 콜레 스테롤 육아종은 안면신경의 고실분절에서 골벽 결손을 유 발하기도 하였고 비진주종성의 경우에 2예, 진주종성의 경 우 7예 관찰되었다.

콜레스테롤 육아종은 만성 중이염이 없이 독립적으로 외 
이도와 추체 첨부에 육아종 혹은 낭종의 형태로 발견될 수 있으며, $6,7,9,14-16)$ 본 연구에서는 4 예에서 유양동과 동시에 안면신경와와 고실동에서 육아종의 형태로 발견되었으나, 독립적이지 않았으며 특히 낭종의 형태나 외이도 및 추체 첨부에서는 보이지 않았다.

콜레스테롤 육아종성 중이염은 고막이 정상이거나, 삼출 성 중이염, 만성 화농성 중이염 및 진주종성 중이염 등의 다 양한 질병군에서 동시에 발생할 수 있고, 정상 고막이거나 재발성 삼출성 중이염의 경우에도 종종 발생하기 때문에 보 존적 치료에도 반응을 하지 않는 경우에는 $\mathrm{CT}$ 혹은 MRI 의 추적검사로 유양동 수술에 대한 결정 여부를 판단하여 야 하며, 수술 시에는 병변을 제거함과 동시에 이관을 포함 하는 중이강과 유양동의 환기뿐 아니라 난청의 원인이 이 소골 파괴로 인한 전음성인 경우가 많으므로 단계적 고실 성형술을 포함하는 이소골 재건도 치료 목적에 포함되어야 하겠다.

\section{REFERENCES}

1) Jaisinghani VJ, Paparella MM, Schachern PA, Le CT. Tympanic membrane/middle ear pathologic correlates in chronic otitis media. Laryngoscope 1999;109(5):712-6.

2) Ferlito $A$, Devaney KO, Rinaldo A, Milroy CM, Wenig BM, Iurato $S$, et al. Clinicopathological consultation. Ear cholesteatoma versus cholesterol granuloma. Ann Otol Rhinol Laryngol 1997;106 (1):79-85.
3) Rinaldo A, Ferlito A, Cureoglu S, Devaney KO, Schachern PA, Paparella MM. Cholesterol granuloma of the temporal bone: a pathologic designation or a clinical diagnosis? Acta Otolaryngol 2005;125 (1): 86-90.

4) Royer MC, Pensak ML. Cholesterol granulomas. Curr Opin Otolaryngol Head Neck Surg 2007;15(5):319-22.

5) Jackler RK, Cho M. A new theory to explain the genesis of petrous apex cholesterol granuloma. Otol Neurotol 2003;24 (1):96-106.

6) Gherini SG, Brackmann DE, Lo WW, Solti-Bhoman LG. Cholesterol granuloma of the petrous apex. Laryngoscope 1985;95 (6):659-64.

7) Nager GT, Vanderveen TS. Cholesterol granuloma involving the temporal bone. Ann Otol Rhinol Laryngol 1976;85 (2 pt 1):204-9.

8) Brackamnn DE, Toh EH. Surgical management of petrous apex chloesterol ganulomas. Otol Neurotol 2002;23 (4):529-33.

9) Paparella MM, Lim DJ. Pathogenesis and pathology of the "idiopathic" blue ear drum. Arch Otolaryngol 1967;85 (3):249-58.

10) Palva T, Lehto VP, Johnsson LG, Virtanen I, Mäkinen J. Large cholesterol granuloma cysts in mastoid. Clinical and histopathologic findings. Arch Otolaryngol 1985;111 (12):786-91.

11) Sadé J, Halevy A, Klajman A, Mualem T. Cholesterol granuloma. Acta Otolaryngol 1980;89(3-4):233-39.

12) Plester $D$, Steinbach E. Cholesterol granuloma. Otolaryngol Clin North Am 1982;15 (3):665-72.

13) Jung TT, Juhn SK. Prostaglandins in human cholesteatoma and granulation tissue. Am J Otol 1988;9 (3):197-200.

14) Miglets AW, Booth JB. Cholesterol granuloma presenting as an isolated middle ear tumor. Laryngoscope 1981;91 (3):410-5.

15) Valavassori GE, Buckingham RA. Middle ear masses mimicking glomus tumor: radiographic and otoscopic recognition. Ann Otol Rhinol Laryngol 1974;83 (5):606-12.

16) Sheehy JL, Linthicum FH Jr, Greenfield EC. Chronic serous mastoiditis, Idiopathic hemotympanum and cholesterol granuloma of mastoid. Laryngoscope 1969;79 (7):1189-217. 